\title{
ANALYSIS OF GENETIC VARIABILITY, ASSOCIATION AND PATH ANALYSIS IN THE HYBRIDS OF SESAME (SESAMUM INDICUM L)
}

\author{
P Sumathi* and V Muralidharan \\ Centre for Plant Breeding and Genetics, Tamil Nadu Agricultural University, Coimbatore-641003, \\ Tamil Nadu, India
}

Accepted: $06^{\text {th }}$ July 2010

\begin{abstract}
A field experiment was conducted with thirty hybrids produced by line $\mathrm{x}$ tester mating design from eleven sesame genotypes involving five branched and six monostem / shy branching types. Observations were recorded on days to $50 \%$ flowering, days to maturity, plant height, number of branches per plant, number of capsules per plant, capsule length, capsule breadth, number of seeds per plant, 100 seed weight, seed yield per plant and oil content. The traits, number of branches per plant, number of capsules per plant and seed yield per plant showed high PCV and GCV estimates. There is scope for selection based on these characters, and the diverse genotypes can provide materials for a sound breeding programme. High heritability combined with high genetic advance (as per cent of mean) observed for plant height, number of branches, number of capsules and seed yield per plant showed that these characters were controlled by additive gene effects and phenotypic selection for these characters would likely to be effective. Seed yield per plant showed significantly positive correlation with plant height, number of branches per plant, number of capsules per plant, days to $50 \%$ flowering, days to maturity and 100 seed weight. Capsule breadth showed significantly negative association with seed yield per plant.
\end{abstract}

Key words: Sesame, variability, co-efficient of variation, heritability and Genetic Advance

\section{INTRODUCTION}

Sesame is one of the important and world's oldest edible oilseed crops. It is the $6^{\text {th }}$ most important oilseed crop grown in India. Though sesame occupies a place of prominence among oilseeds, its production has been relatively low as compared to other oilseed crops. The major constraints identified for most of the countries including India are, instability in yield, lack of wider adaptability, drought, non - synchronous maturity etc. As sesame's world production has to be maintained and even expanded, several key breeding objectives must be attained. Efforts to develop enhanced germplasm for use by the breeders in crop improvement are therefore a necessity. It is essential to generate more variability. The success of any crop improvement programme essentially depends on the nature and magnitude of variability present in the crop. The study of interrelationship of yield components is imperative to enable the selection of sesame genotypes. The present investigation was carried out to gather information on variability, heritability and genetic advance and to determine the association between yield and yield components in hybrids and parents including branched and single stemmed genotypes of sesame.

*Corresponding author: sumivetri@yahoo.com

\section{MATERIALS AND METHODS}

Experimental material for the present study consisted of eleven sesame genotypes involving five female parents, CO 1, Paiyur 1, TMV 3, TMV4, TMV5, (branched) and six male parents viz., MT 34, Cordebergea, KS 990812, KS 99037, KS 990813 and KS 99153 and were crossed in line $\mathrm{x}$ tester mating design. The resulting 30 hybrids along with their parents were raised during kharif 2005 at Department of Oilseeds, Centre for Plant Breeding and Genetics, TNAU, Coimbatore, in a randomized block design with three replications. Each plot consisted of three rows of $4 \mathrm{~m}$ length spaced at $45 \mathrm{~cm}$ between rows and $30 \mathrm{~cm}$ between plants. Normal recommended cultural practices and plant protection measures were followed. Ten competitive plants were randomly selected for recording biometrical measurements on days to $50 \%$ flowering, days to maturity, plant height, number of branches per plant, number of capsules per plant, capsule length, capsule breadth, number of seeds per plant, 100 seed weight, seed yield per plant and oil content. The data were subjected to statistical analysis. The phenotypic and genotypic coefficient of variability was computed as per Burton, 1952. Heritability in broad sense was computed by the formula suggested by Lush (1940). Genetic ad- 
vance was worked out as per the formula given by Johnson et al., (1955). Correlation coefficients for yield and yield components were evaluated utilizing the formula suggested by Al-jibouri et al, (1958).

\section{RESULTS AND DISCUSSION}

Analysis of variance revealed highly significant differences among genotypes for all the characters except capsule breadth (Table 1) indicating considerable amount of genetic variation present in the material. High magnitude of variation in the experimental material was reflected by high values of mean and range for almost all the characters. The estimates of genetic parameters like genotypic coefficient of variation, heritability and genetic advance are presented in table 2. Data indicate that the traits plant height, number of capsules per plant and seed yield per plant recorded highest phenotypic and genotypic variation than the other characters studied.

Table 1. Analysis of variance for different characters in sesame

\begin{tabular}{|c|c|c|c|c|}
\hline \multirow{2}{*}{$\begin{array}{l}\text { Sl. } \\
\text { No }\end{array}$} & \multirow[t]{2}{*}{ Characters } & \multicolumn{3}{|c|}{ Mean squares } \\
\hline & & Replication & Treatment & Error \\
\hline 1 & $\begin{array}{l}\text { Plant height } \\
\text { (cm) }\end{array}$ & 406.02 & $1345.88^{* *}$ & 105.07 \\
\hline 2 & $\begin{array}{l}\text { No. of primary } \\
\text { branches per } \\
\text { plant }\end{array}$ & 8.31 & $25.14^{* *}$ & 3.93 \\
\hline 3 & $\begin{array}{l}\text { No. of cap- } \\
\text { sules/ plant }\end{array}$ & 536.46 & $6508.04^{* *}$ & 317.43 \\
\hline 4 & $\begin{array}{l}\text { Days to } 50 \% \\
\text { flowering }\end{array}$ & 108.11 & $50.80^{* *}$ & 14.78 \\
\hline 5 & $\begin{array}{l}\text { Days to maturi- } \\
\text { ty }\end{array}$ & 58.12 & $82.62 * *$ & 3.23 \\
\hline 6 & $\begin{array}{l}\text { No. of seeds/ } \\
\text { capsule }\end{array}$ & 136.72 & $98.11^{* *}$ & 31.83 \\
\hline 7. & $\begin{array}{l}100 \text { seed } \\
\text { weight }(\mathrm{g})\end{array}$ & 0.00019 & $0.0018 * *$ & 0.0003 \\
\hline 8. & $\begin{array}{l}\text { Capsule length } \\
\text { (cm) }\end{array}$ & 0.00098 & $0.0632 * *$ & 0.0096 \\
\hline \multirow[t]{2}{*}{9.} & $\begin{array}{l}\text { Capsule } \\
\text { breadth }(\mathrm{cm})\end{array}$ & 0.005 & 0.0033 & 0.0029 \\
\hline & Oil content $(\%)$ & 1.008 & $4.145^{* *}$ & 0.5351 \\
\hline 10. & $\begin{array}{l}\text { Seed yield/ } \\
\text { plant }\end{array}$ & 24.78 & $144.68 * *$ & 12.97 \\
\hline
\end{tabular}

$*$ Significant at 5\% ** Significant at $1 \%$

\section{COEFFICIENT OF VARIATION}

The phenotypic coefficient of variation (PCV) was greater than genotypic coefficient of variation (GCV) for all the characters studied, indicating that the environment had an important role in the expression of these characters. The traits, number of branches per plant, number of capsules per plant and seed yield per plant showed high PCV and GCV estimates. There is enough scope for selection based on these characters, and the diverse genotypes can provide materials for a sound breeding programme. Saravanan and Nadarajan (2003) and Solanki and Deepak Gupta (2003) reported high coefficient of variation for number of branches per plant and number of capsules per plant. High coefficient of variation for number of capsules per plant was also reported by Anitha vasline et al., (2000). Plant height showed moderate PCV and GCV and the remaining traits recorded low PCV and GCV. Sudhakar et al. (2007), and Shadakshari et al. (1995) reported low phenotypic and genotypic coefficient of variation for the characters days to fifty per cent flowering, days to maturity and oil content. Low co efficient of variation for number of seeds per capsule was reported by Thangavel et al., (2000).

\section{HERITABILITY}

The heritability estimates obtained (Table 2) were high for all the characters studied except capsule breadth, which recorded very low heritability for these hybrids and parents. Estimates of heritability and genetic advance in combination are more important for selection than heritability alone. High heritability combined with high genetic advance (as per cent of mean) observed for plant height, number of branches, number of capsules and seed yield per plant showed that these characters were controlled by additive gene effects and phenotypic selection for these characters would likely to be effective. Similar results were reported by Reddy et al. (2001) and Krishnaiah et al. (2002). The improvement of the characters days to fifty per cent flowering, days to maturity, number of seeds per capsule and 100 seed weight is also possible since these characters had high heritability and moderate genetic advance as per cent of mean. Capsule length and oil content showed high heritability with low genetic advance. These results are in conformity with the findings of Reddy et al.,2001 and Sudhakar et al., 2007. Capsule breadth showed low heritability and 
low genetic advance which may be due to non additive gene action.

\section{ASSOCIATION ANALYSIS}

Yield is a complex quantitative trait, greatly influenced by environmental fluctuations. Hence, selection based on yield performance alone may give a biased result and leads to ambiguity. A study of nature and degree of association of component characters with yield assumes greater importance for fixing up characters that play a decisive role in influencing yield. Selection would, therefore, be more effective, if it is based on component characters rather than directly on yield. Correlation coefficient analysis measures the mutual relationship between various characters and is used to determine the component character on which selection can be done for improvement in yield.

Seed yield per plant showed significantly positive correlation with plant height, number of branches per plant, number of capsules per plant, days to $50 \%$ flowering, days to maturity and 100 seed weight (Table 3). Capsule breadth showed significantly negative association with seed yield per plant. Similar results were reported by Pawar et al. (2002); and Sankar and Kumar (2003) for plant height; Ramireddy Kumar and Sundaram (2002) and Sankar and Kumar (2003) for number of branches; Ramireddy Kumar and Sundaram (2002), Pawar et al. (2002) and Sankar and Kumar (2003) for number of capsules per plant.

Plant height showed significantly positive correlation with number of branches per plant, number of capsules per plant, days to $50 \%$ flowering, days to maturity and 100 seed weight. Earlier reports of Ramireddy kumar and Sundaram (2002) and Sankar and Kumar (2003) revealed the positive association of plant height with number of branches per plant and number of capsules per plant. Number of branches per plant showed significantly positive inter - correlations with number of capsules per plant, days to $50 \%$ flowering, days to maturity, 100 seed weight. Reddy et al., (2001) and Pawar et al., (2002) reported the positive association of number of branches per plant with number of capsules per

Table 2. Estimates of parameters of variability for yield and its components

\begin{tabular}{|c|c|c|c|c|c|c|c|c|c|}
\hline $\begin{array}{l}\text { Charac- } \\
\text { ters }\end{array}$ & Mean & Range & $\begin{array}{l}\text { Genotypic } \\
\text { variance }\end{array}$ & $\begin{array}{l}\text { Phenotypic } \\
\text { variance }\end{array}$ & $\begin{array}{l}\text { Genotypic } \\
\text { coefficient } \\
\text { of } \\
\text { variation }\end{array}$ & $\begin{array}{l}\text { Phenotyp- } \\
\text { ic coeffi- } \\
\text { cient of } \\
\text { variation }\end{array}$ & $\begin{array}{l}\text { Heritabil- } \\
\text { ity } \\
\%\end{array}$ & $\begin{array}{l}\text { Genetic } \\
\text { advance as } \\
\text { percent of } \\
\text { mean }\end{array}$ & SE \\
\hline $\begin{array}{l}\text { Plant } \\
\text { height } \\
(\mathrm{cm})\end{array}$ & 121.26 & $48.6-153.7$ & 413.60 & 448.63 & 16.77 & 17.47 & 92.2 & 33.17 & 8.37 \\
\hline $\begin{array}{l}\text { No. of } \\
\text { primary } \\
\text { branches / } \\
\text { plant }\end{array}$ & 6.66 & $0.33-11.87$ & 7.07 & 8.38 & 39.94 & 43.48 & 84.4 & 75.56 & 1.62 \\
\hline $\begin{array}{l}\text { No. of } \\
\text { capsules/ } \\
\text { plant }\end{array}$ & 152.85 & $21.1-22.6$ & 2063.54 & 2169.35 & 29.72 & 30.47 & 95.12 & 59.71 & 14.55 \\
\hline $\begin{array}{l}\text { Days to } \\
50 \% \\
\text { flowering }\end{array}$ & 46.28 & $35.3-52.3$ & 12.01 & 16.93 & 7.49 & 8.89 & 70.90 & 12.99 & 3.14 \\
\hline $\begin{array}{l}\text { Days to } \\
\text { maturity }\end{array}$ & 86.15 & $74.3-94.3$ & 26.46 & 27.54 & 5.97 & 6.09 & 96.1 & 12.06 & 1.47 \\
\hline $\begin{array}{l}\text { No. of } \\
\text { seeds/ } \\
\text { capsule }\end{array}$ & 56.63 & $40.6-65.2$ & 22.09 & 32.70 & 8.93 & 10.87 & 67.6 & 15.12 & 4.61 \\
\hline $\begin{array}{l}100 \text { seed } \\
\text { weight } \\
\text { (g) }\end{array}$ & 0.33 & $0.29-0.38$ & 0.0005 & 0.0006 & 6.81 & 7.39 & 84.9 & 12.91 & 0.01 \\
\hline $\begin{array}{l}\text { Capsule } \\
\text { length } \\
\text { (cm) }\end{array}$ & 2.58 & $2.33-2.97$ & 0.02 & 0.02 & 5.18 & 5.62 & 84.9 & 9.82 & 0.08 \\
\hline $\begin{array}{l}\text { Capsule } \\
\text { breadth } \\
(\mathrm{cm})\end{array}$ & 0.72 & $0.67-0.80$ & 0.0011 & 0.0011 & 1.57 & 4.57 & 11.75 & 1.10 & 0.04 \\
\hline $\begin{array}{l}\text { Oil con- } \\
\text { tent }(\%)\end{array}$ & 41.59 & $39.3-43.73$ & 1.38 & 1.38 & 2.64 & 2.83 & 87.1 & 5.07 & 0.59 \\
\hline $\begin{array}{l}\text { Seed } \\
\text { yield/ } \\
\text { plant }(\mathrm{g})\end{array}$ & 21.04 & $5.8-30.9$ & 48.23 & 48.23 & 31.49 & 33.00 & 91.0 & 61.89 & 2.94 \\
\hline
\end{tabular}


Table 3. Genotypic correlation coefficients between different characters in sesame

\begin{tabular}{|c|c|c|c|c|c|c|c|c|c|c|c|}
\hline $\begin{array}{l}\text { Char- } \\
\text { acters }\end{array}$ & $\begin{array}{l}\text { Plant } \\
\text { height }\end{array}$ & $\begin{array}{l}\text { No. of } \\
\text { branch- } \\
\text { es/ } \\
\text { Plant }\end{array}$ & $\begin{array}{l}\text { No. of } \\
\text { cap- } \\
\text { sules/ } \\
\text { plant }\end{array}$ & $\begin{array}{l}\text { Days to } \\
50 \% \\
\text { flower- } \\
\text { ing }\end{array}$ & $\begin{array}{l}\text { Days to } \\
\text { maturi- } \\
\text { ty }\end{array}$ & $\begin{array}{l}\text { No. of } \\
\text { seeds/ } \\
\text { capsule }\end{array}$ & $\begin{array}{l}100 \\
\text { seed } \\
\text { weight }\end{array}$ & $\begin{array}{l}\text { Cap- } \\
\text { sule } \\
\text { length }\end{array}$ & $\begin{array}{l}\text { Capsule } \\
\text { breadth }\end{array}$ & $\begin{array}{l}\text { Oil } \\
\text { con- } \\
\text { tent }\end{array}$ & $\begin{array}{l}\text { Seed } \\
\text { yield } \\
\text { /plant }\end{array}$ \\
\hline $\begin{array}{l}\text { Plant } \\
\text { height }\end{array}$ & 1.000 & $0.949 * *$ & $0.860 * *$ & $0.872 * *$ & $0.894 * *$ & -0.163 & $0.632^{*}$ & -0.323 & -0.333 & 0.407 & $0.824 * *$ \\
\hline $\begin{array}{l}\text { No. of } \\
\text { prima- } \\
\text { ry } \\
\text { branch- } \\
\text { es }\end{array}$ & & 1.000 & $0.833 * *$ & $0.919 * *$ & $0.976^{* *}$ & -0.349 & $0.701 * *$ & -0.3628 & -0.415 & 0.241 & $0.835^{* *}$ \\
\hline $\begin{array}{l}\text { No. of } \\
\text { cap- } \\
\text { sules/ } \\
\text { plant }\end{array}$ & & & 1.000 & $0.741 * *$ & $0.772 * *$ & -0.1855 & 0.601 & -0.2834 & $-0.786^{* *}$ & 0.293 & $0.92 * *$ \\
\hline $\begin{array}{l}\text { Days to } \\
50 \% \\
\text { flower- } \\
\text { ing }\end{array}$ & & & & 1.000 & $0.947 * *$ & -0.2358 & 0.429 & $-0.595^{*}$ & -0.1900 & 0.308 & $0.682 * *$ \\
\hline $\begin{array}{l}\text { Days to } \\
\text { maturi- } \\
\text { ty }\end{array}$ & & & & & 1.000 & -0.3523 & 0.547 & -0.4153 & $-0.548 *$ & 0.366 & $0.766^{* *}$ \\
\hline $\begin{array}{l}\text { No. of } \\
\text { seeds/ } \\
\text { capsule }\end{array}$ & & & & & & 1.000 & -0.204 & $0.594 *$ & 0.2814 & 0.434 & -0.031 \\
\hline $\begin{array}{l}100 \\
\text { seed } \\
\text { weight }\end{array}$ & & & & & & & 1.000 & -0.2392 & $-0.883 * *$ & 0.094 & $0.566^{* *}$ \\
\hline $\begin{array}{l}\text { Cap- } \\
\text { sule } \\
\text { length }\end{array}$ & & & & & & & & 1.000 & 0.0074 & -0.205 & -0.263 \\
\hline $\begin{array}{l}\text { Cap- } \\
\text { sule } \\
\text { breadth }\end{array}$ & & & & & & & & & 1.000 & -0.477 & $-0.953 * *$ \\
\hline $\begin{array}{l}\text { Oil } \\
\text { content }\end{array}$ & & & & & & & & & & 1.000 & 0.413 \\
\hline
\end{tabular}

*Significant at $\mathbf{P}=\mathbf{0 . 0 5} \quad * *$ Significant at $\mathbf{P}=\mathbf{0 . 0 1}$

Table 4. Direct and indirect effects of different characters towards grain yield at genotypic level in Sesame

\begin{tabular}{|c|c|c|c|c|c|c|c|c|c|c|}
\hline Characters & $\begin{array}{l}\text { Plant } \\
\text { height }\end{array}$ & $\begin{array}{l}\text { No. of primary } \\
\text { branches }\end{array}$ & $\begin{array}{l}\text { No. of cap- } \\
\text { sules/ plant }\end{array}$ & $\begin{array}{l}\begin{array}{l}\text { Days to } 50 \% \\
\text { flowering }\end{array} \\
\end{array}$ & $\begin{array}{l}\text { Days to } \\
\text { maturity }\end{array}$ & $\begin{array}{l}\text { No. of seeds/ } \\
\text { capsule }\end{array}$ & $\begin{array}{l}100 \text { seed } \\
\text { weight }\end{array}$ & $\begin{array}{l}\begin{array}{l}\text { Capsule } \\
\text { length }\end{array} \\
\end{array}$ & $\begin{array}{l}\begin{array}{l}\text { Capsule } \\
\text { bredth }\end{array} \\
\end{array}$ & $\begin{array}{l}\begin{array}{l}\text { Oil } \\
\text { content }\end{array} \\
\end{array}$ \\
\hline Plant height & 1.22 & 1.15 & 1.04 & 1.06 & 1.08 & -0.20 & 0.77 & -0.39 & -0.404 & 0.494 \\
\hline $\begin{array}{l}\text { No. of primary } \\
\text { branches }\end{array}$ & -2.98 & -3.14 & -2.61 & -2.88 & -3.06 & 1.096 & -2.20 & 1.14 & 1.30 & -0.76 \\
\hline $\begin{array}{l}\text { No. of capsules/ } \\
\text { plant }\end{array}$ & 0.44 & 0.42 & 0.51 & 0.38 & 0.39 & -0.094 & 0.30 & -0.14 & -0.398 & 0.15 \\
\hline $\begin{array}{l}\text { Days to } 50 \% \text { flow- } \\
\text { ering }\end{array}$ & 0.83 & 0.87 & 0.71 & 0.95 & 0.90 & -0.22 & 0.41 & -0.57 & -0.18 & 0.294 \\
\hline Days to maturity & 1.12 & 1.22 & 0.97 & 1.18 & 1.25 & -0.44 & 0.68 & -0.52 & -0.69 & 0.46 \\
\hline $\begin{array}{l}\text { No. of seeds/ cap- } \\
\text { sule }\end{array}$ & 0.03 & 0.06 & 0.03 & 0.04 & 0.06 & -0.16 & 0.032 & -0.09 & -0.045 & -0.07 \\
\hline 100 seed weight & 0.33 & 0.37 & 0.32 & 0.23 & 0.29 & -0.12 & 0.53 & -0.12 & -0.47 & 0.05 \\
\hline Capsule length & -0.13 & -0.14 & -0.11 & -0.24 & -0.17 & 0.24 & -0.095 & 0.398 & 0.003 & -0.08 \\
\hline Capsule breadth & 0.06 & 0.074 & 0.14 & 0.03 & 0.098 & -0.05 & 0.16 & -0.001 & -0.179 & 0.09 \\
\hline Oil content & -0.09 & -0.05 & -0.06 & -0.07 & -0.08 & -0.092 & -0.02 & 0.043 & 0.101 & -0.21 \\
\hline $\begin{array}{l}\text { Seed yield } \\
\text { /plant }\end{array}$ & 0.82 & 0.83 & 0.92 & 0.68 & 0.77 & -0.03 & 0.57 & -0.26 & -0.96 & 0.42 \\
\hline
\end{tabular}

Residual effect $=0.5154$

Bold figures are direct effects 
plant. Similarly, number of capsules per plant recorded positive correlation with $50 \%$ flowering, days to maturity, 100 seed weight but showed negatively significant association with capsule breadth. Days to fifty per cent flowering showed positive association with days to maturity and negative association with capsule length. Days to maturity revealed positive association with 100 seed weight and number of seeds per capsule showed positive association with capsule length. Path analysis (Table 4) revealed that plant height, number of capsules per plant, days to fifty per cent flowering, days to maturity, 100 seed weight and capsule length showed positive direct effect to seed yield. While number of branches, number of seeds per capsule, capsule breadth and oil content showed only negative direct effect on seed yield. Positive association of number of branches per plant on seed yield is due to the indirect effect of plant height, capsules per plant, days to flowering and maturity.

The present study suggested that the selection based on the characters, plant height, number of branches per plant, number of capsules per plant, and seed yield per plant would be effective for the development of sesame through breeding.

\section{REFERENCES}

Al-Jibouri HA, Miller PA and Robinson HF 1958. Genotypic and environment variances and covariances in an upland cotton cross of interspecific origin. Agron. J., $50: 633-636$

Anitha Vasline Y, Saravanan K and Ganesan J 2000. Studies on variability and genetic advance for certain characters in mutant populations of sesame (Sesamum indicum L.). Sesame and Safflower Newsl., 15 : 39-43

Burton GW 1952 Quantitative inheritance in grasses. Proc. Sixth Int. Grassland Congr. 1: 277283

Deepa Sankar P and Ananda Kumar CR 2003. Genetic analysis of yield and related components in sesame (Sesamum indicum L.) Crop Res. 25 (1) : 91-95

Johnson HW Robinson HF and Comstock RE 1955.
Estimation of genetic and environmental variability in soybean. Agron . J. 47: 314-318

Krishnaiah G, Reddy KR and Sekar MR 2002. Variability studies in sesame. Crop Research, 24: 3, 501-504

Lush JL 1940. Intrasine correlation and regression of offspring on dams as a method of estimating heritability of characters. Proc. Amer. Soc. Anim. Nutr. 32: 293-301

Pawar KN, Chetti MB and Shamrao Jahagirdar, 2002. Association between seed yield and yield attributing characters in sesamum (Sesamum indicum L.) Agri. Sci. Digest, 22(1) : $18-20$

Ramireddy Kumar A and Sundaram T 2002. Interrelationships among yield and yield components in sesame (Sesamum indicum L.) J. Res. ANGRAU 30 (2): 42-44

Reddy PAV, Sekar MR, Ranganatha ARG and Dhanraj A 2001. Genetic variability and heritability for seed yield and its components in sesame (Sesamum indicum L.). Journal of Oilseeds Research, $18: 2$, 173-175

Saravanan S and Nadarajan N 2003. Combining ability studies in sesame. Crop Res. 25(2) : 319 $-324$

Shadakshari YG, Virupakshappa K and Shivashankar G 1995. Genetic variability studies in germplasm collection of sesame (Sesamum indicum L.). Mysore Journal of Agricultural Research, 29:133-137

Solanki ZS and Deepak Gupta 2003. Variability and character association among quantitative characters of sesame. J. Oilseeds Res. 20 : 276-277

Sudhakar N, Sridevi O and Salimath 2007. Variability and character association analysis in sesame, Sesamum indicum L. Journal of Oilseeds Research, 24 : 1, 56-58.

Thangavel P, Saravanan K, Senthil Kumar P, Anbuslvan, Y and Ganesan J 2000. Variability, heritability and genetic advance in sesame (Sesamum indicum $\mathrm{L}$ ) Sesame and Safflower Newsl., $15: 19$ - 22. 